\title{
Vital force as a triangulated concept of nature and $s(S)$ pirit
}

\begin{tabular}{|c|c|}
\hline $\begin{array}{l}\text { Authors: } \\
\text { Kuzipa M.B. N } \\
\text { Johan Buitend }\end{array}$ & $\begin{array}{l}\text { alwamba } \\
\operatorname{ag}^{1,2} \text { (1) }\end{array}$ \\
\hline $\begin{array}{l}\text { Affiliations: } \\
\text { }{ }^{1} \text { Department } \\
\text { and Christian } \\
\text { of Theology, U } \\
\text { Pretoria, South }\end{array}$ & $\begin{array}{l}\text { f Dogmatics } \\
\text { thics, Faculty } \\
\text { niversity of } \\
\text { Africa }\end{array}$ \\
\hline $\begin{array}{l}{ }^{2} \text { Council for W } \\
\text { South Africa }\end{array}$ & orld Mission, \\
\hline $\begin{array}{l}\text { Research Proje } \\
\text { Project Leader } \\
\text { Project Numb }\end{array}$ & $\begin{array}{l}\text { ct Registration: } \\
\text { J. Buitendag } \\
\text { er: } 02402343\end{array}$ \\
\hline $\begin{array}{l}\text { Description: } \\
\text { Dr Kuzipa M.B. } \\
\text { participating ir } \\
\text { project, 'Theol } \\
\text { directed by Pro } \\
\text { Buitendag, De } \\
\text { Dogmatics and } \\
\text { Ethics, Faculty } \\
\text { University of P }\end{array}$ & $\begin{array}{l}\text { Nalwamba is } \\
\text { the research } \\
\text { ogy of Nature', } \\
\text { f. Dr Johan } \\
\text { partment } \\
\text { Christian } \\
\text { of Theology, } \\
\text { retoria. }\end{array}$ \\
\hline $\begin{array}{l}\text { Note: } \\
\text { This article is a } \\
\text { version of aspe } \\
\text { PhD thesis of K } \\
\text { Nalwamba, titl } \\
\text { as a Triangulat } \\
\text { Nature and s(S } \\
\text { Department of } \\
\text { and Christian E } \\
\text { of Theology, U } \\
\text { Pretoria with P } \\
\text { Buitendag as s }\end{array}$ & $\begin{array}{l}\text { reworked } \\
\text { ects from the } \\
\text { Kuzipa M.B. } \\
\text { ed 'Vital Force } \\
\text { ed Concept of } \\
\text { ) pirit', in the } \\
\text { fogmatics } \\
\text { thics, Faculty } \\
\text { niversity of } \\
\text { 'rof Johan } \\
\text { upervisor. }\end{array}$ \\
\hline $\begin{array}{l}\text { Corresponding } \\
\text { Kuzipa Nalwam } \\
\text { knalwamba@g }\end{array}$ & $\begin{array}{l}\text { author: } \\
\text { nba, } \\
\text { smail.com }\end{array}$ \\
\hline $\begin{array}{l}\text { Dates: } \\
\text { Received: } 23 \text { Ja } \\
\text { Accepted: } 09 \\
\text { Published: } 26 \mathrm{~J}\end{array}$ & $\begin{array}{l}\text { an. } 2017 \\
\text { Mar. } 2017 \\
\text { June } 2017\end{array}$ \\
\hline Read online: & \\
\hline 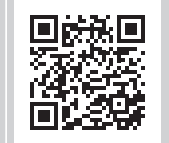 & $\begin{array}{l}\text { Scan this QR } \\
\text { code with your } \\
\text { smart phone or } \\
\text { mobile device } \\
\text { to read online. }\end{array}$ \\
\hline
\end{tabular}

This article explores and seeks to appropriate theologically the African notion of vital force as a relational, non-reductionist ecological concept that would enrich the Christian doctrine of pneumatheology. The understanding that relational and pneumatological categories are viable within the theology-science dialogue is the broader framework within which this article is conceived. The relationship between natural theology and revelation provides an epistemological standpoint that does not divorce Spirit and reality.

\section{Introduction}

Vital force is presented here from an eco-hermeneutical perspective as a viable concept of nature and $s(S)$ pirit in dialogue with Christian tradition and the scientifically derived concept of force fields. Such a conversation provides for a mutually accountable approach to reality that tempers absolutising tendencies that arise from understanding based on transcendent revelation on one hand and innate reality on the other. A conceptual exploration of the notion of vital force as a nonreductionist idea of nature and spirit takes seriously the African cultural and intellectual resources as well as other ways of knowing.

The emphasis on life (vitality) and its interrelatedness are fundamental aspects of the African culture. A retrieval of the notion of vital force within the purview of African culture and thought therefore speaks to the African notion of be-ing undergirded by a conception of an enchanted universe. Such an understanding of the universe has the potential to engender positive attitudes towards nature.

\section{Literature}

Vital force has been affirmed as representative of African ontology and cosmology. This notion has been theologically appropriated and apprehended on African terms by the likes of Kaoma (2013), Sakupapa (2012), Magesa (1997, Nkemnkia (1999), Nkurunziza (1989), Nyamiti (1976) and Kagame (1956) and applied to a variety of themes in theology. Hitherto, no study has attempted to explore and articulate the notion of African vital force as a pneumatheological concept in reference to nature and spirit with an underlying emphasis on the interrelatedness of the divine and creation and of creation within itself.

Kaoma (2013:70-71) has attempted an exploration of the concept of vital force from an ecohermeneutical perspective. His reference is, however, limited to three paragraphs in a section titled 'Vital Force: The Spirit That Holds the Universe Together' in his book God's Family, God's Earth: Christian Ecological Ethics of Ubuntu. He relies on Nkemnkia's (1999) African Vitality whose view is that the vital force not only constitutes human but also non-human life. It is in itself a promising lead albeit within the boundaries of a study whose focus is not on the concept itself. Aside from Nkemnkia (1999) and Kaoma (2013), Sakupapa (2012) in his article titled 'Spirit and Ecology in the Context of African Theology' published in the journal Scriptura suggests a trajectory for the eco-pneumatological potential of vital force and explores various dimensions it could potentially address within African theology and as a contribution to Christian ecological discourse.

This article therefore picks up from Kaoma and Sakupapa's allusions to the eco-pneumatological potential of the concept of vital force. Sakupapa's conclusion is an appropriate point of departure for this article. Sakupapa (2012) ends by asserting and recommending that:

African theology has the potential to contribute to the discourse on Christian responses to the ecological crisis if it can articulate a pneumatology that takes into account the African intellectual and cultural

How to cite this article: Nalwamba, K.M.B. \& Buitendag, J., 2017, 'Vital force as a triangulated concept of nature and s(S)pirit', HTS Teologiese Studies/Theological Studies 73(3), 4506. https://doi.org/10.4102/hts.v73i3.4506

Copyright: () 2017. The Authors. Licensee: AOSIS. This work is licensed under the Creative Commons Attribution License. 
infrastructure in its theologising. The articulation of how such an ecological pneumatology would look is a task for further research. (p. 429)

\section{A pneumateological view of creation}

The notion of vital force recalls the belief that human beings form part of the community of life within the realm of the cosmic spirit. That assertion may seem like a truism that should not require any further enunciation within Christianity. However, belief in the Creator-Spirit, a pneumatological understanding of creation, is fairly young in the Christian tradition. In Colossians 1:15-20, Christ is presented as instrumental to creation. Christian tradition has often understood and presented creation in Christological terms.

The filioque issue of the Nicaeno-Constinopolitanum is based on that and is a question that requires revision in light of a pneumatheological view of creation. Christianity's complicity to causes of the ecological crisis McFague is arguably an indication that the foundational belief in a Spirit-CreatorGod has not historically characterised or undergirded Christian belief about creation.

The Christian faith therefore stands to benefit from 'companion' and alternative ways of seeing the world that affirm the cosmic Spirit and goes beyond Christianity. The African notion of vital force is understood to be at the centre of the universe, which is understood as an organic whole. The web of life of life, understood to have been brought into being, is sustained by and inhabited by the vital force and apprehended in terms of the cosmic Spirit.

Further still, the retrieval of the concept of vital force for appropriation for eco-pneumatheology reflects a pressing issue of our time, namely, the ecological crisis we face. It is in keeping with the Christian tradition that Christian literature, including the Bible, reflects the pressing questions of our time. Theological expression and the transmission of the Christian faith in our times are thus couched in terms of the ecological crisis as the pressing issue we need to wrestle with in our time.

Faraday's force field theory states that 'power which electrical currents may possess of inducing any particular state upon matter in their immediate neighbourhood, otherwise indifferent' (Faraday 1849:1). Vital force, cosmic Spirit and force fields therefore nuance views of the creator Spirit, for an eco-pneumatheological hermeneutic and ethic because the telling of the story of the universe cannot be confined to one view. It is against this background that this article explores the African concept of vital force for an ecopneumatheological application. The presupposition is that the African notion of vital force has the potential to enrich Christian ecological reflection as a cultural resource to the Christian family.

\section{Vitalism: Background}

Vitalism as a philosophical concept has its origins in lifeoriented movements that sought to challenge a civilisation that had become intellectualistic and in many respects considered anti-life. The contestation about life, which led to sharp contrasts between what was deemed to be living as opposed to dead or non-living, was quite intricate. The distinction between what was living and what was dead became a criterion for cultural criticism among cultural theorists such as Friedrich Nietzsche, Henri Bergson and George Simmel. Traditional ways were examined in the light of whether they represented authentic life or they denied life (Schnadelbach 1984).

Vitalism has also been critiqued in biology where it is understood as something separate from bodies and as that which animates bodies. The argument probably goes back to Gilbert Ryle's 1949 critique of a 'ghost in the machine' in reference to intentional agency (Ryle 2009). His was a critique of the traditional Cartesian doctrine of the mind-body dualism and the ghost-like way of understanding vitalism. In the estimation of some, Ryle's view dealt Cartesian dualism a fatal low by depicting the mind as a philosophical illusion concocted by the Cartesian categories.

In his book, What is Life?, physicist Erwin Schrödinger (1944) applied quantum physics to the understanding and definition of life and came to the conclusion that, in the interaction between organisms and their environments, there was a balance between entropy ${ }^{1}$ and negative entropy. The drawing of negative entropy from its environment means there is a continual exchange of energy on which the survival of the organism depends. As Buitendag (2012:4) puts it: 'Through the exchange of energy, life is consolidated and equilibrium is averted'. ${ }^{2}$

In our view, vital force is an anti-reductionist notion that seeks to say something about the way organisms move. In other words, it is about the discernment of movement (i.e. energy). The concept of vitalism can be retrieved as long as the ghost-like way of speaking is avoided. In humans, this has to do with charisma, personality and a sense of purpose, as earlier stated.

Vitalism, as grounding for critical theory, has been contested mainly because of the forms that it has tended to take in the past, namely, mysticism and occultism (Jones 2010:57). Some philosophers discount it altogether as a basis for any critical theory even while maintaining life's cultural resonance and power in light of the life-threatening emergence of ecological questions and the power of technology (Jones 2010:4). While critical of vitalism, Jones (2010) is able to affirm that:

Life cannot be reduced to physicochemical matter and the emergent properties of life and the ascending nature of living

1.A measurable physical quantity of the specific heat of any given substance which when altered sets in motion a process towards a chaotic state (Schrödinger 1944).

2.'Deur die uitruil van energie word lewe gekontinueer en die fatale toestand van ekwilibrium afgeweer'. 
systems cannot be understood in terms of mechanistic or quantitative science modelled on the operation of machines or Newtonian physics. (pp. 4-5)

Nancey Murphy holds a similar view and disavows reductionism in defining human nature and, by extension, nature in general. Murphy advances a two-pronged argument: firstly, she is against reductionism and advocates for upwards causation (emergence). Secondly, she argues for self-direction by and autonomy of the human being in choosing behaviour based on moral reasons. This selfdirection, she reckons, derives from the use of selected information from the environment, which the human being uses to make choices.

Murphy (2006:89-91) thus concludes that there is within human nature an ability to represent to oneself as an aspect of one's own processes. She argues against physicalism from scientific data and notes the dearth of scientific support for the dualism that has shaped Christian understanding for ages. She understands God's actions in the world as being at a quantum ${ }^{3}$ level. Within that conception, there can be no conflict with natural causation within nature for that reason. If nature is understood as a 'physical' being, then from this perspective it is possible to say with Murphy (2006:131) that 'the natural world is intrinsically incomplete and open to divine action at its most basic level'. Moreover, if there is openness to divine action at that most basic level, would it not then be probable to argue that God is (ontologically?) present to that effect in all of creation?

Despite her critique of vitalism, Jones affirms that life cannot be understood in reductionistic terms. She notes how the debate about vitalism has transcended everyday scientific concepts and reached for something more that is grounded in life. She characterises that 'something' as being 'both biologistic and spiritualist, naturalist and theological' and that it 'may not have an essence but only be the name for the set of multiple doctrines and movements premised on life variously understood' (Jones 2010:7). Hence, to that extent, Murphy and Jones make the same basic point.

Deane-Drummond (2008:13-15) gives an appreciative appraisal of the value of going back to sources of ecological wisdom and taking serious insights that emerge from the various lenses. Each has potential to reveal nature as something that can be esteemed as God's creation. However, she warns about the danger of polarisation of insight that arises from the different human perceptions of nature. Idolisation of nature (as is the case in deep ecology) may also be possible if the concept of vital force being appropriated metaphorically in this study is idealised rather than critically engaged with.

I appreciate the African concept of vital force, particularly for its anti-reductionist view of nature, which in Kelsey's (2009) parlance is eccentricity. Humans postulate that quality to be a 3.This is understood here as the minimum amount of an entity involved in an interaction. critique of the reductionist ways and mechanistic approaches to nature that ultimately lead to the domination of the rest of creation. African vital force could therefore form a basis for an eco-pneumatology augmented by ecological wisdom that is imbedded in the African context. That wisdom postulates that the vital energy that brings forth, imbues and holds all of creation together, also sustains it as a community of life. Yet before we can make that application, it is important to explore that notion of vital force and to outline its contours.

\section{African notion of vital force}

Despite the contestation of Tempels' idea of vital force, African theologians and thinkers have endorsed the concept to varying degrees. The objections to Tempels' articulation of the notion of vital are mainly on three counts. Firstly, the critique is about positing a distinct African way of thinking abounds among African professional philosophers who hold that Tempels' characterisation, rather than valorise African thinking, in fact, contributes to imaging Africa as 'different'. The discourse of African difference is characteristically a product of colonial discourse. Maluleke (1997:29) has in fact argued that Tempels' work 'was not ... directed at the African's or understanding's sake, but for the benefit of the colonials and missionaries'. Poignantly, Tempels' last chapter in his Bantu Philosophy is titled 'Bantu Philosophy and our mission to civilise'. That locates Tempels' work as a product of his age as is borne out by that chapter. Furthermore, the portrayal of Africans as objects (rather than subjects) of study in Tempels' work is problematic from a postcolonial standpoint.

Those criticisms notwithstanding, Tempels' contribution lies in his contribution to African cosmological interpretation using the idea of vital force, which he understood as encapsulating all of life in African thought. In this conception, each being is imbued with a vital force that enables life, which explains how that energy relates to ontology. In his own words, 'Force is the nature of being, force is being, being is force' (Tempels 1959:44).

Hountondji (1979) presents an incisive qualified damnation and what seems like a tongue-in-cheek part-acclamation of Tempels' Bantu Philosophy, when he contends that his work is aimed:

on the one hand at facilitating what it calls 'mission to civilise' (by which we understand practical mastery by the coloniser of the black man's [sic] psychological well springs) and, on the other hand, at warning Europe itself against the abuses of its own technocratic and ultra-materialistic civilisation, by offering her, at the cost of a few rash generalisations, an image of the fine spirituality of the primitive Bantu. (p. 49)

Conversely, but without excusing or defending the colonial bias in Tempels, Okafor quips that we cannot expect him 'to shed every bias of his time, despite his protestations' (Okafor 1982:89). Taking that caveat into account, one would equally argue that Tempels' ethnography was quite advanced for his time. He provided what would become a 
basis for African studies that would mark a new epoch of taking African experience relatively seriously within the context of colonisation.

Vincent Mulago (1969:148), Charles Nyamiti (1976:170), Vahakangas (1999:285) and John Mbiti (1969:10) also take issue with Tempels' notion of vital force. It is, however, not entirely clear what their substantive objection is. Mbiti, for instance, ambivalently argues that Tempels' thesis 'is open to a great deal of criticism, and (that) the theory of vital force cannot be applied to other African peoples' while pointing out that its main contribution 'is more in terms of sympathy and change of attitude than perhaps in the actual contents and theory of his book'.

Young (1985:64) has argued that Mbiti (1969 and Idowu (1975) object to Tempels' seeming reduction of African traditional religion to magic. Masolo (1994) offers an analysis of the thematic areas, debate and participants in the African philosophy's quest for an identity in both English and French regions. His conclusion is that Africa's peculiar circumstances have shaped it in ways of constructing reality and acquiring meaningful knowledge, which includes contestation of imposed identities.

For the purpose of this article, I pick up on Tempels' thesis that vital force recalls the biocentric impulse in African ontology and its potential to heighten our sensibilities to the intrinsic value of all of life (creation) in all of its interrelatedness. Analogically understood, therefore, vital force is the cosmic spirit that is ontologically present in (and enfolds) all of creation and which indeed unfolds itself in all modes of be-ing. Vital force in African cosmology is therefore the cosmic animating potent force that interpenetrates all that is, without being identical to it.

Ramose (1999:51) articulates the underpinnings of African philosophical thought as grounded in the notion of $u b u-n t u$, understood 'as a whole-ness and a constant flow of be-ing'. To the extent that vital force $(n t u)$ flows through the entire universe, one may argue that vital force enfolds organic and inorganic forms of life and all modes of being. These themes have been explored from various angles by Africanist theologians, thinkers and philosophers.

In the African context, human life is inseparably bound to nature in the same way that human beings are defined by their connection to the totality of the community of life (Gitau 2000). The African notion inhabits a bio-centric theology and philosophy that celebrates 'pan-vitalism', as Asante (1985) terms it and that he explains as 'Reality (be-ing) inseparable' (1985). He notes the inseparable nature of reality in the African notion and the kinship of all creatures. Additionally, Sindima (1990) underlines the importance of an underlying matter which he argues is important because:

How we think about the world affects the way we live in it. In particular, our understanding of nature - our cosmology - affects ... the way we relate to the earth and other forms of life. For some time the people of Africa have been influenced by a cosmology inherited from the West: the mechanistic perspective that views all things as lifeless commodities ... to be used for human ends. Yet these people have an alternative way of looking at the world, an alternative cosmology, which can better serve their cultural development and social justice in an ecological context. This alternative may be called a life-centred way, since it stresses the bondedness, the interconnectedness of all living being. (pp. 137-138)

The third objection to Tempels' thesis is the contention on how widespread the notion of vital force is among Africans, if at all. That question has been self-evidently answered through the number of African scholars who have appropriated the concept. Even those who have qualms about the concept as discussed above have somehow found resonance with some of the associations that Tempels made to the idea of vital force.

Mulago's union vitale and participation vitale nuances the concept of vital force further by recalling the African understanding that God (however God is understood in various African cultures) is essentially vital force. God is, in Tempels' parlance, the Supreme Being whose life force is imbued in all creatures and that that vital force permeates and connects the interrelated web of 'dynamic and intricate relationships' (Kaoma 2013) within the web of life. Mulago's union-of-life-in-participation is instructive and therein we identify that to which the vital force may be applied. It recalls the pneumatological category of relationship and participation, which echo the biblical tradition.

Other African theologians have underlined the need to harness such insights for ecological theology. Ghanaian, Emmanuel Asante, has coined the term pan-vitalism which, in my view, further nuances Mulago's union vitale. Asante 1985 avers that in the African conception:

Reality is inseparable. The African is kin to all creatures - gods, spirits and nature ... The whole of nature must be understood as sacred because it derives its being from the Supreme Being who is the Creator-Animator of the Universe. (pp. 290, 292)

Malawian, Harvery Sindima, characterises the African concept as based on the 'bondedness, sacredness and fecundity' (Conradie 2004:109) of what he terms the 'community of life'. He holds that the:

African idea of community refers to bondedness; the act of sharing and living in the one common symbol - life - which enables people to live in communion and communication with each other and nature ... (which) allows the stories or life experiences of others to become one's own. (Sindima 1990:537)

Of all the objections to Tempels' conception of vital force, two seem to be valid: firstly, his insistence on the difference between African and European notions of being, which has been deemed to perpetuate the colonial discourse about African difference. Secondly, he is accused of the methodological error of generalising about Africa. There is no attempt here to adjudicate these varied positions, but merely to postulate that, those objections notwithstanding, 
there is something retrievable from Tempels' notion of vital force. By looking at various ways (i.e. triangulating) in which the concept of vital force has been applied, I am persuaded that vital force is an adequate concept of nature and spirit. It opens up the African concept and reality as unified and participative within the realm of interconnected and interdependent beings.

\section{Vital force in theological perspective}

In the African concept, vital force finds its expression in the interrelatedness of the divine, the ancestors (Nkemnkia 1999), the living and nature. This is exemplified in the ritual life of the African life cycle. All living beings - including God, spirits and ancestors - share in the vital force. Even inorganic things share in the life force because the African universe is so imbued with potency. Every object is a religious symbol that connects human beings to the unseen by pointing beyond them to the transcendent realm. In traditional Christian parlance, we could say that in the African universe every object is potentially sacramental, if we understand sacrament as referring to 'an external action or rite or object that communicates God or in which one encounters God' (Jensen 2008:62). When we construe the presence of vital force in inorganic objects as 'sacramental presence', we secure the argument against any pantheistic connotations that may be read into this claim.

The 'vital force' then is a fundamental value in African thought and all things, animate and inanimate, are grounded in it. It 'is the creative force behind all human and non-human action' (Nel 2008:40), and according to Setiloane (1998:80), it is an 'interpenetrating and permeating' influence that saturates the community of life. Setiloane (1998) asserts that in African thought all creation emanates from a single source, therefore:

[T] he term community is inclusive of all life (bios): animals, the habitat [the land], flora, and even the elements. The success of life is found in the ability to maintain a healthy relationship with all. (p. 79)

Nel (2008) extends upon Setiloane's cosmological assertion by framing this relational inclusivity in terms that confirm that an ethic of eco-responsibility may emanate from African cosmology. McFague (2008) aptly captures that sacramental sensibility when she advances that the world lives within God' and further offers that 'God and the world are not two separate realities that exist independently and must somehow find each other. Rather, the world is "charged" with God as with electricity' (McFague 2008:115).

She construes that the Spirit is the milieu in whom (Ac 17) everything exists. In incarnational terms, she speaks of life as being with and in God. She concludes that:

This understanding says that we live within the body of God; that the world is, and is not the body of God; and that all things exist within the one reality that is and that reality is on the side of life and fulfilment. God as Spirit is the power of life and love within which all bodies exist. (McFague 2008:116)
The inclusivity suggested by this interpenetrating and permeating power of vital force or Spirit in the universe recalls the imbedded and embodied nature of life. The implication is that this could engender moral responsibility towards the community of life in view of the ecological crisis the world faces. The convergence between African thought and Christian tradition is in critical relationship with anthropocentric views that have historically become imbedded in Christian tradition and are complicit with human dominance of the rest of creation to its detriment.

Though conceptually and cosmologically spaced out, the ideas of the sacramental nature of creation in Christianity, the concept of vital force as the milieu of life in African thought and the notion of field force as theologically appropriated from scientific study, all have important convergence points. These make them viable conversation partners in the articulation of grounding pneumatological and relational categories within ecological discourse that could shape an eco-pneumatology.

In African traditional life therefore, the meaning of life is bound up in the dialectic of the collective. As a result, when humans are spoken of as a subject, they can only be spoken of in terms of relationship with 'others'. That means human beings are not subjects in the abstract but are subjects in relation to other subjects.

The ecological crisis that we face in the world could be characterised as a tremendous loss of equilibrium and a reminder that human relations with the 'other' in creation is in disequilibrium. The reason for this is because human beings have ceased to see the glory of God in everything in the world. McFague (2008) captures our human failure aptly when she admonishes that:

We must undergo the deepest of all conversions, the conversion from egocentrism to theocentrism; a conversion to whom we truly are: reflections of God, as is everything in creation. The only difference between us and the rest of creation is that the others reflect God, tell of God, simply by being, whereas, we must will that it be so. We must desire ... to live justly and sustainably on earth with all other creatures. (p. 115)

In African understanding, the 'other' includes God, the living and the living dead and all that is in the environment. Everything is interrelated, and therefore life should be lived in balance for the flourishing of all of creation. The sacredness, bondedness and fecundity of the community of life therefore dictated the rhythm of traditional African life. As Sindima (1990) observes:

The African idea of community refers to bondedness; the act of living and sharing in one common symbol - life - which enables people to live in communion and communication with each other and nature. Living in communication allows stories or life experiences of others to become one's own. (p. 537)

In African traditional life, communal ritual action is therefore at the very core of life. In an African sense, then, all vicissitudes of life could be said to hinge on the vital force as the 
'realm' of life. The rites of passage that have to do with the human life cycle encompass those practices, customs and ceremonies performed to mark the various stages of life from conception to death. These rituals affirm the sacredness of each stage and they invoke God's participation. Lugira (2009) narrates how the Banyarwanda and Barundi of East Africa ritualise God's participation in conception. This ritual is called Amziy'mana [God's water]. Every woman who anticipates conception always keeps a bowl of water in her room before going to bed. The preservation of the life of the foetus during pregnancy continues to be a co-operative venture. The mother-to-be is subject to food taboos and other restrictions aimed at preserving the life of the unborn child. The pregnant woman herself is considered as chosen for the sacred duty of bringing a new life to the community in this co-operative act with the divine.

Conception and birth rituals indicate God's presence in the child's life from the moment of conception. Water is a symbol of God's tool for the creation of a human person. John 3 refers to the mother's womb and water for rebirth. Water is also a ritual symbol of cleansing in the newborn's transition from the mother's womb into the world and it is used to mark other life cycle transitions like the initiation of boys and girls into adulthood in some cultures. The initiate is taken to the stream to wash and emerges a man or woman, ready to be incorporated into the community as an adult with accompanying adult responsibilities. The ritual washing echoes the symbolic initiation through the water of baptism, which initiates and incorporates the believer into the body of Christ.

There is an interactive participative synergy between the Divine and the water in the act of conception and various initiation stages in African traditional life. The relational lifegiving process of which the Divine is participant in the creative activity is reminiscent of the pneumatological hermeneutic of creation according to Michael Welker (1999). He argues for a creation model that transcends the conventional guiding conceptions of creation that uphold a causation/production model that depicts God as a static prime cause and/or mover. Instead, God is presented as a relational participant within the creatio continua understanding of creation.

In that view of creation, Welker (1999) notes that:

God reacts to the presence of what is created ... through perception and evaluation ... intervening in what is already created, intervening for the purpose of further specification ... (in which) the divine and human initiative coincide (Gen 2:5). (pp. 9-10)

The flourishing and survival of the primordial garden is dependent, not on God's first act of production, rather it is dependent on the cooperation of other factors (like rain) and human initiative. In this regard, we might conjecture that God reacts to the potency within the realm of creation. It is plausible to presume provisionally that God's reaction is to the vital force.
We derive an ethic from the use of water as a ritual symbol in the traditional African context that water is much more than a commodity for utility. Water is considered as ritually connected to our very being through its participative link to the divine in the act of conception. Such a primal characterisation of water is complemented by the reference to the 'water' of the womb as the incubator of life. The association with the divine in the act of conception is within the realm of the vital force. The divine association confers water with a sacred shroud and imbues it with potency to participate in the impartation and renewal of life of which the divine is a participant too. It is reminiscent of the creatio continua. The attendant emergent understanding in which the created is bequeathed with agency in the act of creation is compatible with the water birth ritual symbol.

There is a long-standing understanding that water is the most important element that constitutes life. There is historically no consensus about water being the basic element of life, but there is agreement that life as we know it cannot exist without water. The view of water as a primeval element of life is reminiscent of the Milesian philosopher, Thales, of the fifth-century BC. He advanced the view that water was the basic element that constituted life. Thales seemed to opt out of mythological explanations of his time that water was the primary element of life $e^{4}$ by advancing a physical explanation. He certainly offered a comprehensive cosmology that concluded that everything was water (Zeller 1963). Thales' attempt to transcend the absolute in favour of the holistic is evident.

Aristotle questioned Thales' postulation without necessarily contradicting the assertion about water but rather questioning the general principle of all principles being understood as material in nature. Aristotle, however, considered water (and fire) to be 'simple homoeomerous elements's (Cherniss 1971:219). He considered Thales' position trustworthy without subscribing to mythical accounts about gods that held a similar opinion as Thales. Thales postulated that the earth itself rested on water. Aristotle construed his position to have derived from the fact that all things are nourished by moisture. Heat itself is sustained by moisture and seeds have a moist nature. The conclusion then was that water is the source/origin of everything that is moist ${ }^{6}$ (Cherniss 1971).

In philosophy, religion and science the quest for cosmological unity is prevalent as part of the human quest for cosmological congruence and water has played a major factor in that quest in many cultures. In Chinese philosophy water is one of the five basic elements of life, the others being, earth, fire, wood and metal. Many religions, including Christianity, understand water to be the source of life itself. In the Genesis 1 creation

4.See Cherniss (1971:218-219). Greek philosophers already held to the view that there were four basic elements of life, namely, earth, air, fire and water. Thales departed from that and singled out water as the basic element of life.

5. Homoeomerous referring to a substance consisting of similar parts recalls the Aristotelian philosophical dialectic of whether the universal is essentially present in its particulars. See Ross (1924:cvii, 132-133) for extended commentary on Aristotle's position.

6.See http://classics.mit.edu/Aristotle/metaphysics.1.i.html (viewed 27 August 2015). 
narrative, the ruach of God is presented as hovering over the chaotic primordial waters. Water is also used for religious ritual cleansing as a symbol of renewal or rebirth (cf. Jn $3 ; 1$ Jn 5:6-8).

In some African cultures, the placenta and umbilical cord of the newly born are buried under a tree. From then on, until it bears fruit, that tree is considered scared. When the fruit matures, it is used to prepare a sacred feast for the community. The community includes all participants in the mystery of conception, birth. The tree is linked to this mysterious act as recipient of the same nourishment as the newly born, but also as bearer of the fruit that in turn feeds and nourishes the community.

Ecologically, the symbolism of the tree being nourished by water and the bodily elements of humans recalls the community to the shared interdependent existence. Even in death, the cycle of life remains constant; dead creatures and organisms become nourishment for plants and other creatures in the lower strata of the food chain. Thus, the rituals surrounding pregnancy and birth and that underlie the African notion are a reminder of relationality and the interdependence that undergird the web of life.

Within such an interdependent web, even death is an acceptable natural part of the life cycle (Lugira 2009). The life cycle is just that, LIFE-cycle, because even death leads to (becomes) life. The solidarity between the living and the living dead has been appropriated by some African theologians as ecclesiologically, Christologically and eschatologically relevant (see Mbiti 1979; Pobee 1979; Sawyer 1970). The ecotheological appropriation takes the interrelatedness of life beyond the human sphere to include all of life. Hence, the underlying respect for life that the concept of vital force entails is carried through, not only beyond death but to be ecologically relevant. Interaction within relationship is self-extension. Interrelations therefore regenerate and renew - that is the essence of life. Be-ing is in becoming (see Jungel 2014). ${ }^{7}$ The very origins of life in African traditional mythology cannot be understood without including death. Creation myths recount the origins of human beings and all created beings alongside death (Lugira 2009).

\section{African vital force as a pneumatheological concept}

Vital force captures the participative interaction between the Life-giver (God) and the totality of reality within a vital dynamism that is at the core of being, apart from being understood to be at the core of the pattern of African understanding of life. In the Genesis narrative, according to Welker, God reacts to what has been created. Welker (1999) proposes that:

The creating God is not only an acting God, but also a reacting god who responds to what has been created. The creating God is

7.Eberhard Jungel has written a book by this title, which marks the self-communicative movement through which God makes God's present to us. God's sending the Son in movement through which God makes God's present to us. God's sending the Son in
the unity of the Spirit into the world which overcomes the antitheses of 'being' and the unity of the open to being confronted by the independence, the originality, even the need for improvement of that which has been created. (and that) ... The creature's own activity which is itself a process of production, is not only a consequence and result of creation that is already completed. Rather it is embedded in the process of creation and participates in the process. (pp. 10-11; cf. esp. Gen 1:11ff.)

Culture creating is exemplified by the task divinely assigned to the human to name the animals and to tend the garden. Cultivation of the garden does not depend on human activity alone but requires the rain to participate in the life-giving activity of the flourishing of the garden. In Genesis 1 and 2 then, God is at the receiving (responsive) end of the creation itself within a creatio continua frame of understanding. Welker (1999:10) argues that fundamentally and apparently (in a way that 'only a distorting abstraction can block out') in the first two chapters of Genesis, God's action is action that 'let's itself be determined'. God's action is action that reacts to creation.

I construe then that vital force is that vital dynamism that can be discerned in terms of its causal efficacy and which could be interpreted in terms of Christian pneumatology as the creating, sanctifying and renewing Spirit of God. Whitehead's exploration of how actual entities come to be and develop into an interconnection is presented as movement (or upwards trend) towards order rather than chaos (Hartshorne \& Peden 2010). Vital force construed as 'presence' within which divine action takes place appropriates the Spirit's work and action in non-interventionist terms, in terms of contributory efficacy and interrelationship within that 'presence'. That contributory efficacy and interrelationship can be characterised as movement.

The term perichoresis ${ }^{8}$ has been used theologically to apply to the hypostatic mutually interpenetrating relationship within the Triune Godhead - Father, Son and Holy Spirit (Bergmann 2005) as well as to the incarnation in reference to the two natures of Christ. The understanding in that reference is that the divine nature of Christ and his human nature mutually penetrate each other without fusing and without becoming interchangeable. It is in that sense that we construe the divine Spirit's interpenetrating nature, lovingly nourishing, renewing and making it flourish, without becoming identical with it.

The involvement of the effect (i.e. the created) in the cause (i.e. God) runs counter to traditional Christian belief. God is traditionally understood as the One who exists, from whose divine nature all creation issues without qualification and is intelligible only within Godself. In process theology, God is understood in panentheistic terms, transcending the polarities of immanence and transcendence (Griffith \& Smith 2001).

8 Rigby (2007) highlights how contested the term 'perichoresis' has been historically while here. No reconciliation of the contested views is attempted, only to delineate the term for the specific way in which it advances the discussion here. See also Chapter 4 of this study. 
The vital force, understood as Spirit, is relational and could be portrayed as the creating, life-giving, renewing, sanctifying Spirit of God. The Spirit's life-affirming movement in action and presence are elucidated under the rubric of theories of divine action in nature that transcend interventionistic views of God (Wildman 2013). The vital force, understood as the Spirit that holds the universe together, is seen as a forceful lifeaffirming relational presence, not merely as an interventionistic force experienced as a nebulous transcendence.

Non-interventionistic theories of divine action ${ }^{9}$ understand God as being at work 'creatively and redemptively in and through the natural world to bring it to healing and wholeness' (Edwards 2010:xiii) in relational terms, not as a divine autocratic force that intervenes in the universe in an arbitrary fashion. God is understood as One who created an emergent universe and who lovingly relates to it, lives in, with and beyond it and respects (and even lives within and responds to) the limits of the ontological structure of creation.

On the other hand, those who hold a purely interventionistic view exclude any compatibility with non-interventionistic views (and that is largely the Christian traditional view). They also hold:

that the laws of nature reflect the deep ontological structure of reality as God created it and are happy to imagine that God might act in nature by ignoring or violating those rules of nature. (Wildman 2013:148)

Non-interventionist views are many and nuanced and leave room for divine intervention that defies laws of nature without being absolute - as the Christ-event illustrates. As Buitendag (2009:509) argues, 'Neither absolutisation of transcendent revelation, nor that of immanent knowledge of nature, provides an accountable understanding of reality'. The important thing is not to overstate interventionism, rather to hold it in a health tension with a scientifically informed non-interventionism that 'leaves ontological room for God to act in this world without breaking God's own rules for its operation' (Wildman 2013:149).

Because everything is understood to be interconnected and related through the shared principle of life, the vital force, life in the African context, is presumed to be the greatest good and the aim of be-ing. Gabriel Setiloane (1995) valorises such a biocentric focus in the African way of life and argues that this element would enrich the Christian view of God.

The concept of vital force therefore provides a viable conceptual framework for an eco-pneumatology that is not just relevant to African Christian theology in the African context alone but is a gift to Christian theology as well. The articulation of an eco-pneumatology that is grounded on vital force can conceptually be applied to the Christian understanding of participation in the common life (Mulago 1969 which connects the human family to God. The divine

9.Divine action is understood here not in terms of conclusive views of how God actually acts for I believe that to be as beyond human fathoming God's own nature is. What is attempted is to articulate characteristics of God's action that may illuminate the subject at hand.
African cosmology is the ultimate source of all life and in whom all life holds together, and is not at odds with biblical foundations and science. It thus contributes to Christian discourse on the ecological crisis.

Vital force brings to the fore the pervasiveness of the Spirit as the spring of life, on which the interrelated participation of all of creation hinges. The risk of sustaining this analogy about the Spirit in non-interventionist terms can seem to err on the side of making the Spirit too immanent.

This article presents vital force as a concept of nature and Spirit within the broader sphere of the ecological crisis. The portrayal is therefore necessarily in corrective terms. Sustaining the argument that the Spirit is present in, with (and yet far beyond) nature could, for that reason, seemingly commit the immanentistic error. The caution is heeded while pleading the focus and context of the study as the caveat. It also becomes clearer in the course of the discussion what views I have on immanentism as such.

Life and participatory interrelationships are vital themes in the scripture as some theologians have eloquently commented (see Dunn 1998; Edwards 2006; Moltmann 1992). The social doctrine of the Trinity is a category in theology that has implications on the cosmic scope of the Spirit. Bergmann sees that in terms of 'new possibilities interpreting the relational being of nature' (Bergman 2005:283). It is within this kind of emphasis on the cosmic spirit, which has gained currency in pneumatological studies, that the African concept of vital force finds its conversation partners and its contribution.

Krister Stendahl (1990:49) speaks of the 'energy of life'; Mark Wallace has introduced a representation of a biocentrically focused 'Green Face of God', which he based on scriptural images (see Gen 1:2, Ps 104:29-30 - vivifying breath; Jdg 6:34 healing wind; Jn 3:6 - living water; Ac 2:1-4 - divine dove ). Elizabeth Johnson speaks of the Spirit in cosmic terms as 'the dynamic flow of divine power that sustains the universe, bringing forth life ... (and as the) indwelling, renewing, moving' (Johnson 1993:42). The Spirit who is the Creator and who renews Creation brings all creatures into communion.

Peter Hodgson (1994) speaks of the Spirit as the cosmic Eros, described in the following compelling words:

God's love for the world is erotic in the sense that God creates, desires and allures the world in its vitality and materiality, while at the same time transfiguring that materiality into relationships ... of recognition, mutuality, self-giving. (p. 194)

From an African point of view, then, the Creator whose vital force animates all of creation brings human beings into an ontological relationship with all of creation. This pneumatic understanding is analogical to the underpinning notion in Christian theology of God whose Spirit imbues all creation and calls all of creation into participation. The reverence for life that ensues from such a view is so deeply valued in the African way of life that it is a viable foundation for an ecological ethos and serves as grounding for ethics of 
responsibility in earth care because everything is interrelated and interdependent.

The health of the whole community of life ensures the wellbeing of each kind - and humans are keenly aware of that, and perhaps we need other (lower) creatures for survival more than they need us. There might be a recovery of the idea of the cosmic Spirit as the power of God that gives life (ruach or vital force), who is the indwelling Spirit-giver, sustainer of a layered and co-existent way of being that is not limited by binaries or the concrete material world. The Spirit makes possible a unity of reality in which immanence and transcendence are inextricably bound together as the realm of reality in which the presence of God may be discerned. This cosmic breadth of the Spirit is apprehended within a Trinitarian frame of reference and understood as One who enables communion in the web of life within broader redemptive and eschatological dimensions of Christian theology.

\section{Acknowledgements Competing interests}

The authors declare that they have no financial or personal relationships which may have inappropriately influenced them in writing this article.

\section{Authors' contributions}

This article is a reworked version of aspects from the PhD thesis of K.M.B.N., titled 'Vital Force as a Triangulated Concept of Nature and s(S)pirit', in the Department of Dogmatics and Christian Ethics, Faculty of Theology, University of Pretoria with J.B. as supervisor.

\section{References}

Asante, E., 1985, 'Ecology: Untapped resource of Pan-Vitalism in Africa', AFER: African Ecclesial Review 27, 289-293.

Bergmann, S., 2005, Creation set free: The spirit as liberator of nature, Wm B Eerdmans, Grand Rapids, MI.

Buitendag, J., 2009, 'Nature as creation from an eco-hermeneutical perspective: From a "natural theology" to a "theology of nature"', HTS Teologiese Studies/Theological Studies 65(1), 509-518. https://doi.org/10.4102/hts.v65i1.272

Buitendag, J., 2012, 'Die noodsaaklikheid van habitat in ons definisie van menswees: Op soek na 'n eko-teologiese verstaan van menslike lewe', HTS Theological Studies 68(1), 1-8. https://doi.org/10.4102/hts.v68i1.1283

Cherniss, H., 1971, Aristotle's Criticism of PreSocratic philosophy, 2nd edn., Octogon Books, New York.

Conradie, E.M., 2004, 'On the integrity of the human person and the integrity of creation: Come Christian theological perspectives', in C. du Toit (ed.), The integrity of the human person in an African context: Perspectives from science and religion, pp. 107-151, Research Institute for Theology and Religion, University of South Africa, Pretoria.

Deane-Drummond, C., 2008, Eco-theology, Anselm Academic, Winona, MN.

Dunn, J., 2006, 'Towards the spirit of Christ: The emergence of the distinctive feature of Christian pneumatology', in M. Welker, D.G. York \& A. York, A (ed.), pp. 3-26, William B. Eerdmans, Grand Rapids, MI.

Dunn, J., 1998, The theology of Paul the Apostle, Wm. B. Eerdmanns, Grand Rapids, MI.

Edwards, D., 2006, Ecology at the heart of faith: The change of heart that leads to a new way on earth, Orbis Books, Maryknoll, NY

Edwards, D., 2010, How God acts: Creation, redemption, and special divine action, Fortress Press, Minneapolis, MN.

Faraday, M., 1849, Experimental researches in electricity, 2nd edn., Richard \& Edward Taylor, London.

Gitau, S., 2000, The environmental crisis: A challenge for African Christians, Acton, Nairobi.
Griffith, D. \&. Smith,K., 2001, Reenchantment without supernaturalism: A process philosophy of religion, Cornell University Press, New York.

Hartshorne, C. \&. Paden, C., 2010, Whitehead's view of reality, Cambridge Scholars Publishing, Cambridge.

Hountondji, P.J., 1979, African philosophy: Myth and reality, Hutchinson University Library for Africa London.

Hodgson, P., 1994, Winds of the spirit: A constructive Christian theology, SCM Press, London.

Hopkins, F., 1913, The dynamic side of biochemistry, British Association, s.I.

Idowu, E., 1975, African traditional religion: A definition, Orbis, Maryknoll, NY.

Jensen, D., 2008. The lord and giver of life: A constructive Christian theology, John Knox Press, Westminster.

Johnson, E., 1993, Women, earth and creator spirit, Paulist Press, Nairobi.

Jones, D., 2010, The racial discourses of life philosophy: Negritude, vitalism and modernity, New Directions in Critical Theory ed. Columbia University Press, New York.

Jungel, E., 2014, Being is in becoming: The Trinitarian of God in the theology of Karl Barth, Bloomsbury Publishing, London.

Kagame, A., 1956, La Philosophie Bantu-Rwandaise de l'étre, Academie Royale des Sciences Coloniale, Bruxelles.

Kaoma, J., 2013, God's family, God's earth: Christian ecological ethics of Ubuntu, Kachere Series, Zomba.

Kelsey, D., 2009, Eccentric existence: A theological anthropology, John Knox, Wesminster.

Lugira, A., 2009, African traditional religion (world religions), 3rd edn., Chelsea House Publishers, New York.

Magesa, L., 1997, African religion: Moral traditions of abundant life, Orbis Books, New York.

Maluleke, T., 1997, 'Half a century of African Christian theologies: Elements of the emerging agenda for the twenty-first century', Journal of Theology in Southern Africa 4-23.

Masolo, D., 1994, African philosophy in search of identity, Indiana University Press, Bloomington, IN.

Mbiti, J., 1969, African religions and philosophy, Heinemann, Oxford.

Mbiti, J., 1979, Concepts of God in Africa, SPCK, London.

McFague, S., 2008, A new climate for theology: God, the world, and global warming, Reprint edn., Fortress Press, Minneapolis, MN.

Moltmann, J., 1992, The spirit of life: A universal affirmation, Fortress Press, Philadelphia, PA.

Mulago, V., 1969, 'Vital participation: The cohesive principle of the Bantu community', in K.A. Dickson \& P. Ellington (eds.), Biblical revelation and African beliefs, Lutterworth Press, London.

Murphy, N., 2006, Bodies and souls, or spirited bodies?, Cambridge University Press, Cambridge.

Nel, P., 2008, 'Morality and religion in African thought', Acta Theologica 2, 33-47.

Nkemnkia, M., 1999, African vitalogy: A step forward in African thinking, Paulines Publications Africa, Nairobi.

Nkurunziza, D., 1989, Bantu philosophy of life in the light of the Christian message: A basis for an African vitalist theology, Peter Lang, New York.

Nyamiti, C., 1976, African tradition and the Christian God, Gaba Publishers, Eldoret.

Nyamiti, C., 1996, 'The Trinity from an African ancestral perspective', Journal of the Catholic University Eastern Africa in African Christian Studies 12(4), 38-74.

Okafor, S.O., 1982, Bantu philosophy: Placide Temples Revisited, Journal of Religion in Africa 13(2), 83-100.

Pobee, J., 1979, Towards an African theology, Abingdon, Nashville, TN.

Ramose, M., 1999, African philosophy through Ubuntu, Mond Books, IN.

Rigby, C., 2007, 'Redeeming words: Hypostatic union and the reading of scripture', in W. Alston \& M. Welker (eds.), Reformed theology: Identity and ecumenicity II: Biblical interpretation in the Reformed tradition, vol. 2, pp. 331-348, Wm. B. Eerdmans Publishing, Grand Rapids, MI.

Ross, W., 1924, 'Introduction', in W. Ross (ed.), Aristotle's metaphysics voulme 1: A revised text with introduction and commentary by W.D Ross, pp. xiii-clxvi, Clarendon Press, Oxford.

Ryle, G. 2009, The concept of the mind: 60th anniversary edition, Routledge, London.

Sakupapa, T., 2012, 'Spirit and ecology in the context of African theology', Scriptura 3(111), 422-430.

Sawyer, H., 1970, God: Ancestor or creator? Aspects of tradtional belief in Ghana, Nigeria and Sierra Leone, Longman, London.

Schnadelbach, H., 1984. Philosophy in Germany, 1831-1933, Cambridge University Press, Cambridge.

Schrödinger, E., 1944, What is life?, Cambridge University Press, Cambridge.

Setiloane, G., 1995, 'Towards a biocentric theology and ethic - Via Africa', Black Journal of Theology 9(1), 52-66.

Setiloane, G., 1998, 'Towards a biocentric theology and ethic - Via Africa', in C. du Toit (ed.), Faith, science and African culture. African cosmology and Africa's contribution to Science, pp. 73-84, Unisa, Pretoria. 
Sindima, H., 1990, 'Community of life: Ecological theology in African perspective', in C. Birch, W. Eaken \& J.B. McDaniel (eds.), Liberating life: Contemporary approaches in ecological theology, pp. 137-147, Orbis Books, Maryknoll, NY.

Stendahl, K., 1990, The energy of life: Reflections on the theme 'Come Holy Spirit Renew the Whole Creation', WCC Publications, Geneva.

Tempels, P., 1959, Bantu philosophy, Editions Réclame, Paris.

Vahakangas, M., 1999, In search of foundations for African Catholicism: Charles Nyamiti's theological methodology, Brill, Leiden.
Welker, M., 1999, Creation and reality, Fortress Press, Minneapolis, MN.

Wildman, W., 2013, 'Robert John Russel's theology of God's action', in N. Hallanger (ed.), God's action in nature's World: Essays in honour of Robert John Russell, pp. 147-169, Ashgate Publishing, Burlinghton, VT.

Young, U.J., 1985, 'Black theologies: Sibling or distant cousins? A critical examination from a North American perspective', PhD dissertation, Union Theological Seminary, New York.

Zeller, E., 1963, Outlines of the history of Greek philosophy, 13th edn., Routledge \& Kegan Paul, London. 